\title{
MODELLING SEDIMENT YIELDS IN ITALIAN CATChMENTS
}

Anton Van Rompaey ${ }^{1,3}$, Paolo Bazzoffi ${ }^{2}$, Robert J.A Jones ${ }^{3}$, Luca Montanarella ${ }^{3}$

${ }^{1}$ Physical and Regional Geography - K.U.Leuven, Belgium \& Fund for Scientific Research, Flanders, Belgium

${ }^{2}$ Instituto Sperimentale per lo Studio e la Difesa dello Suolo - Firenze, Italy

${ }^{3}$ Soil and Waste Unit - Institute for Environment and Sustainability - Joint Research Centre - Ispra (Va), 21020 Italy

Corresponding author:

Anton Van Rompaey

Physical and Regional Geography - K.U.Leuven

Redingenstraat 16, B-3000 Leuven, Belgium

Tel. +32 16326411

E-mail: anton.vanrompaey@geo.kuleuven.ac.be 


\begin{abstract}
Long term sediment yield observations, derived from 40 long term sedimentation records in Italian reservoirs, were used to calibrate and validate the spatially distributed sediment delivery model WaTEM/SEDEM using the best data available at national scale. The sediment yield data set includes records from semi-natural catchments in northern Italy as well and agricultural and semi-natural basins in central and southern Italy. The average size of the catchments is $150 \mathrm{~km}^{2}$ with mean annual sediment yields ranging from 0.20 to 20 ton.ha ${ }^{-1} \cdot \mathrm{y}^{-1}$. WaTEM/SEDEM estimates mean annual sediment fluxes to permanent river channels. Depending on the local transport capacity, the sediment flux is detachlimited or transport limited. The optimal transport capacity parameters for Italian conditions were derived via automatic calibration procedures. A global model calibration procedure taking into account all catchments in the dataset led to an overestimation of the sediment yield for the mountain catchments and and underestimation for the nonmountain catchments. Sediment yield estimates are more reliable when calibration procedures are applied separately for mountain and non-mountain catchments. The results of this exercise suggest that the application of elementary process descriptions is sufficient to produce relatively accurate long-term sediment yield predictions if the spatial configuration of sediment sources and sinks is taken into account.
\end{abstract}

KEYWORDS: Sediment yield, soil erosion, reservoirs, Italy 


\section{INTRODUCTION AND OBJECTIVES}

Human-induced environmental change at a global scale is causing a spectacular increase of geomorphic process activity and sediment fluxes in many parts of the world (e.g. Turner et al., 1990, IGBP-BAHC, 1997, COST Action 623, 1999). The Mediterrean region is particulary susceptible to erosion. This is because it is subject to long dry periods followed by heavy bursts of erosive rainfall, falling in on steep slopes with fragile soils, resulting in considerable amounts of soil erosion.

The consequences of soil erosion and sediment deposition occur both on -and off-site. On-site effects are particulary important on agricultural land where the redistribution of soil within a field, the loss of soil from a field, the breakdown of soil structure and the decline in organic matter and nutrients result in a reduction of cultivable soil depth and a decline in soil fertility. The net effect is a loss of productivity, which at first, restricts what can be grown and results in increased expenditure on fertilizers, but later may lead to land abandonment (Pimentel et al., 1995, Crosson, 1997).

Off-site problems problems result from sedimentation downstream, which reduces the capacity of rivers and retention ponds, enhances the risk of flooding and muddy floods and shortens the design life of reservoirs (Clark, 1985; Boardman et al., 1994 ; Verstraeten and Poesen, 1999). Sediment is also a pollutant in its own right and, through the agro-chemicals adsorbed to it, can increase the levels of nitrogen and phosphorus in water bodies and result in eutrophication (Sibbesen, 1995 ; Steegen et al., 2001).

Not surprinsingly soil erosion and sediment delivery have become important topics on the agenda of local, national and European policy makers. This has led to an increasing demand for reliable scale soil erosion models to delineate target zones in which conservation measures are likely to be the most effective. Secondly, regional scale erosion models were requested to predict the geomorphic response of possible conservation measures at the scale of catchments.

Despite the development of a range of phycically-based soil erosion and sediment transport equations, sediment yield predictions at a regional scale are at present achieved mainly through simple empirical models that relate the annual sediment delivery by a 
river to catchment properties, including drainage area, topography, climate and vegetation characteristics (e.g. Flaxman, 1972, Walling, 1983 ; Onstad, 1984 ; Bazzoffi et al., 1996, Lixian et al., 1996, Verstraeten and Poesen, 2001, Verstraeten et al., 2003).

The main reason why empirical regression equations are still widely used for sediment yield predictions is their simplicity which makes them applicable even if only a limited amount of input data is available. Nevertheless, the predictive ability of this kind of equations is limited to particular regions they have been developped from. Moreover, inherent to a spatially lumped approach is that it is not possible to take into account the spatial structure of land use and topography within the catchment on sediment delivery. This inherently limits its applicability to practical problems such as the evaluation of different land management strategies on sediment delivery.

\section{(FIGURE 1 NEAR HERE)}

\section{Figure 1: Two theorecital land use scenarios (left: with high SY, right with low SY)}

Figure 1 shows two theoretical land use scenarios in a catchment. The percentage of forest is the same in both land use scenarios but their spatial configuration is different. The land use configuration with forest on the upslope parts of the catchment (left on Figure 1) results in a lower sediment yield than an alternative scenario with forest bordering the river (right on Figure 1) as in the second scenario an important fraction of the eroded sediment is trapped before reaching a river channel.

The example described above shows the potential of spatial models that do take into account the spatial configuration of a landscape and the connectivity between sediment sources and river channels. Advanced event-based models such as WEPP (Nearing et al., 1989), LISEM (De Roo, 1996), EUROSEM (Morgan et al., 1998), EROSION-3D (Schmidt et al., 1999) adopt such a spatially distributed approach by routing the eroded sediment from gridcell to gridcell. If the transport capacity at a certain gridcell is not sufficient, depostion occurs. The outcome of these models are spatial patterns of erosion and deposition as a result of single storm events. Their application of these relatively complex spatials models is, however, problematic at the scale of large catchments $(>100$ $\mathrm{km}^{2}$ ) as the quality of the necessery input data is in general not sufficient at these scale levels to succesfully apply the model equations. 
As an alternative for the complex event-based distributed models more robust long-term distributed models such as CAESAR (Coulthard et al., 2000) and WaTEM/SEDEM (Van Oost et al., 2000, Van Rompaey et al., 2001) were developped. They are based on a similar gridcell-to-gridcell routing aim at long-term predictions at regional scale levels. This goal is achieved by aggregating physically-based event-parameters into empirical long-term model-parameters. Hitherto, these long-term spatial sediment yield models have been applied relatively successfully in northern and central Europe: UK (Coulthard et al., 2002), Belgium (Van Rompaey et al., 2002), the Czech Republic (Van Rompaey et al., 2003a) and Germany (Lenhart et al., in press).

The objective of this paper is to examine wether a similar approach is feasable for the prediction of sediment yield in mountain catchments and in catchments with a mediterrenean climate. Therefore a dataset of sediment yield for 40 catchments in Italy was retrieved from sediment deposition rates in reservoirs was made available by the Instituto Sperimentale per lo Studio e la Difesa dello Suolo in Firenze, Italy (ISSDS). Firstly, for each of the catchments all necessary input data for a WaTEM/SEDEM application were prepared. Next, the dataset with observed SY-values was used to calibrate the model parameters. Finally, the correspondence between predicted and observed sediment yield is examined.

\section{SEDIMENT YIELD DATA FOR ITALY}

Bazzoffi et al. (1996) compiled a data set with sediment deposition rates for 40 reservoirs constructed in the 1950's and 1960's throughout Italy (Figure 2). Sediment deposition rates were assessed by direct sonar sub-bottom profiler measurements or derived from estimates and measures made by ENEL (Italian Electricity Power Company) during dredging of the reservoirs.

\section{(FIGURE 2 NEAR HERE)}

Figure 2: Left: Reservoir in Campo-Tartano (Lombardy, Italy), Right: Reservoir in Volterra (Tuscany, Italy) 
The reservoirs were selected from a larger database whereby only reservoirs with a likely sediment trapping efficiency of $100 \%$ were considered. Nevertheless, there is never a $100 \%$ guarantee that that sediment trapped in a reservoir represents the total sediment yield from the watershed in the lapse of time from dam building to survey time. For this reason only 40 watershed-reservoir systems were selected from the database, retaining only the better-known ones respect to management history (Figure 3).

The sediment volumes where converted to mass volumes using a mean bulk density of 0.865 ton. $\mathrm{m}^{-3}$ derived from the direct analysis of sedimentary profiles of 4 reservoirs of the dataset and from the application of equations of Lara and Pemberton (1963) and Lane and Koelzer (1943) for estimating sediment density from grain size distribution and regime of exposition to air of deposits.

The SY-data set includes data from semi-natural alpine basins in the north as wel as agricultural and semi-natural basins in central and south Italy. The average size of the basins is $150 \mathrm{~km}^{2}$, ranging from 11 to $697 \mathrm{~km}^{2}$. The mean annual precipitation ranges from $480 \mathrm{~mm}$ in the south to $2380 \mathrm{~mm}$ in the Alps to the north. The measured areaspecific sediment yield varies between $0.1 \mathrm{tha}^{-1} \mathrm{y}^{-1}$ and $16.8 \mathrm{t} \mathrm{ha}^{-1} \mathrm{y}^{-1}$ (see Table 1)

(TABLE 1 NEAR HERE)

\section{Table 1 Properties of 40 Italian Reservoirs}

The area contributing to each catchment was delineated using a DEM with a resolution of $75 \mathrm{~m} \times 75 \mathrm{~m}$ made available through the GISCO data base of the European Commission. In catchments with a 'cascade system' of reservoirs the area contributing to upslope reservoirs was not taken into consideration.

The sediment yield data show a very heterogeneous spatial pattern. The highest sediment yields (> 8 ton.ha ${ }^{-1} \cdot \mathrm{y}^{-1}$ ) were observed in Sicily and in the northern Apenines. Low SYvalues $\left(<1\right.$ ton.ha $\left.{ }^{-1} \cdot \mathrm{y}^{-1}\right)$ were observed in Alps at the borders with Switzerland and France (see Figure 3).

(FIGURE 3 NEAR HERE) 
Figure 3: Location of 40 catchments with measured SY at the outlet

\section{ESTIMATING SEDIMENT YIELD WITH WaTEM/SEDEM}

\subsection{Model structure}

WaTEM/SEDEM is a spatially explicit sediment delivery model. For a detailed description of the model we refer to Van Rompaey et al. (2001). In this paper only the basic principles are described.

Wether or not eroded sediment is deposited within the basin depends on the travel distance and the characteristics of the travel path. WaTEM/SEDEM requires a layer of mean annual erosion rates and a layer with the location of permanent rivers in the basin as an input. For each pixel of the catchment, the mean annual transport capacity (TC in $t$ $\mathrm{y}^{-1}$ is calculated using the following equation (Equation 1) :

$$
\mathrm{TC}=\mathrm{K}_{\mathrm{TC}} \mathrm{R} \mathrm{K}\left(\mathrm{L} \mathrm{S}-5.3 \mathrm{~S}_{\mathrm{g}}{ }^{0.8}\right)
$$

(Equation 1)

Where :
$\mathrm{R}$ : RUSLE rainfall erosivity
$\mathrm{K}$ : RUSLE soil erodibility in
S : RUSLE slope factor (-)
L : unit specific contributing area (-)
$\mathrm{S}_{\mathrm{g}}:$ slope gradient
$\mathrm{K}_{\mathrm{TC}}$ : transport capacity coëfficient

$\mathrm{K}_{\mathrm{TC}}$ values are land use specific and can be assessed by means of calibration. Once the mean annual soil erosion rate and the mean annual transport capacity are known, a routing algorithm is used to tranfer the eroded sediment from the source to the river network via topographically derived flowpaths. For each grid cell the amount of sediment input is added to the amount of soil erosion in that cell. If the sum of the sediment input and the local sediment production is lower than the transport capacity then all the 
sediment is routed further down slope. If this sum exceeds the transport capacity then the sediment output from the pixel is limited to the transport capacity and there will be a net sediment deposition. This means that sediment transport is detachment limited or transport capacity limited depending on the position in the landscape.

WaTEM/SEDEM assumes that river pixels have an infinitely high transport capacity. This means that all the sediment that is reaches a permanent river channel is delivered to the outlet of the basin. The output of the model consists of a pixel map representing the amount of net erosion and net sediment deposition at each grid cell.

\subsection{Model parameter values}

Mean annual soil erosion rates were assessed using USLE-procedures proposed by van der Knijff et al. (1999, 2002) and Grimm et al. (2003). The USLE (Universal Soil Loss Equation) is an empirical equation originally developped to assess mean annual soil losses at the foot of a linear slope. The equation is as follows (Equation 2) :

$$
\mathrm{A}=\mathrm{R} \mathrm{K} \mathrm{L} \mathrm{S} \mathrm{C}
$$

Where :

$$
\begin{array}{rll}
\mathrm{A} & = & \text { Mean annual soil loss (in } \mathrm{th}^{-1} \mathrm{yr}^{-1} \text { ) } \\
\mathrm{R} & = & \text { Rainfall erosivity factor (in } \mathrm{MJ} \mathrm{mm} \mathrm{ha}^{-1} \mathrm{~h}^{-1} \mathrm{yr}^{-1} \text { ) } \\
\mathrm{K} & = & \text { Soil erodibility factor (in } \mathrm{th} \mathrm{MJ}^{-1} \mathrm{~mm}^{-1} \text { ) } \\
\mathrm{L} & = & \text { Slope length factor (dimensionless) } \\
\mathrm{S} & = & \text { Slope factor (dimensionless) } \\
\mathrm{C} & = & \text { Cover management factor (dimensionless) }
\end{array}
$$

Desmet and Govers (1996) expanded the model with 2D-routing algorithms, wich allows the application of the USLE-equation at complex 2D-landscapes. USLE-2D in which the the one-dimensional slope-length factor $(\mathrm{L})$ is replaced with an unit upslope area $\left(\mathrm{L}_{2 \mathrm{D}}\right)$ incorporates soil loss by gully erosion (Desmet et al. 1999). 
Grimm et al. (2003) derived rainfall erosivity values for Italy from monthly total rainfall data $\left(\mathrm{P}_{\text {monthly }}\right)$ at 366 meteorological stations for the period 1931 to 1960 . The point data were interpolated using nearest-neighbour analysis. Monthly rainfall erosivity values

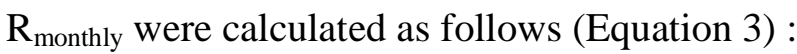

$$
\mathrm{R}_{\text {monthly }}=1.3 * \mathrm{P}_{\text {monthly }} \quad \text { (Equation 3) }
$$

Where :

$$
\begin{aligned}
& \mathrm{R}_{\text {monthly }} \text { : the monthly rainfall erosivity factor (in } \mathrm{MJ} \mathrm{mm} \mathrm{ha}{ }^{-1} \mathrm{~h}^{-1} \mathrm{yr}^{-1} \text { ) } \\
& \mathrm{P}_{\text {monthly }} \text { : the total monthly rainfall (in } \mathrm{mm} \text { ) }
\end{aligned}
$$

Grimm et al. (2003) derived soil erodibility values (K) were derived soil texture data made available through the $1: 250000$ soil map of Italy using an equation proposed by Römkens et al. (1986) (Equation 4) :

$$
K=0.0034+0.0405 * \exp \left[-0.5\left(\frac{\log D g+1.659}{0.71}\right)^{2}\right] \quad \text { (Equation 4) }
$$

Where :

$$
\begin{aligned}
& \mathrm{K} \text { : soil erodibility factor (in } \mathrm{t} \mathrm{h} \mathrm{MJ}^{-1} \mathrm{~mm}^{-1} \text { ) } \\
& \mathrm{D}_{\mathrm{g}} \text { : geometric mean weight diameter of the primary soil particles (in } \mathrm{mm} \text { ) }
\end{aligned}
$$

Vulcanic soils have an erodibility beyond the range that is predicted by Equation 4 . Therefore an erodibility value of $0.08 \mathrm{t} \mathrm{h} \mathrm{MJ}^{-1} \mathrm{~mm}^{-1}$ was assigned to all volcanic soils (Dino Torri, personal communication).

Van der Knijff et al. (1999) assessed monthly cover management factor values for Italy using Advanced Very High Resolution Radiometer imagery (AVHRR) with a ground resolution of $1 \mathrm{~km}^{2}$. AVHRR-imagery was used to calculate NDVI-values. Next the NDVI values were linked with cover management factors (C) using the following function (Equation 5) 


$$
C=\exp \left[-2 \cdot \frac{N D V I}{1-N D V I}\right]
$$

Where :

$\mathrm{C}:$ cover management factor (-)

NDVI : normalised difference vegetation index (-)

As NDVI is only sensitive for healthy, photosynthetically active vegetation, C-values are unrealistically high for forest in winter months. Therefore the maximum monthly cover management factor for woodland was defined at 0.01 .

Slope gradient (S) and slope length (L) factors were calculated using a 75 DEM made available through the GISCO database of the European Commission. A flux decomposition algorithm developped by Desmet and Govers (1996) was used to assess the upslope area of each grid cell. Next the equations proposed by McCool et al. (1987, 1989) were used to assess the topographic factor LS.

Eventually for each grid cell of $75 \mathrm{~m} \times 75 \mathrm{~m}$ a mean annual erosion rate (A in ton.ha ${ }^{-1} \cdot \mathrm{y}^{-1}$ ) was assessed using the following equation (Equation 6) :

$$
A=\sum_{i=1}^{12} R_{i} \cdot K_{i} \cdot C \cdot L \cdot S \quad \text { Equation } 6
$$

The transport capacity (TC, Equation 1) was assessed using RUSLE-parameters calculated with the same procedures and data as described above. Transport capacity coefficients $\left(\mathrm{K}_{\mathrm{TC}}\right)$ were assessed by means of calibration for different land cover types.

\subsection{Model calibration}

Parameter values for WaTEM/SEDEM are available for landscapes in central Belgium (Van Rompaey et al., 2002), the Czech Republic (Van Rompaey et al., 2003a) and South Africa (Van Rompaey et al., 2003b). The catchments in the Italian dataset presented here 
are characterised by completely different landscapes than than the previously mentioned studies. Moreover, Van Rompaey et al. (2001) reported that optimal WaTEM/SEDEM parameters are dependent on the quality and the resolution of the input data. Therefore, model parameters proposed in other model application are not necesserily valid.

Given the limited number of data in the dataset only the transport capacity parameters for arable land $\left(\mathrm{K}_{\mathrm{TC}-\mathrm{A}}\right)$ and for forest/pasture $\left(\mathrm{K}_{\mathrm{TC}-\mathrm{FP}}\right)$ were calibrated. The parameters used in the erosion component of the model were not calibrated against the SY-dataset as the calibration of multiple parameters leads to equifinality problems. The CORINE land cover data (GISCO-database) was used to delineate the two land use categories.

The calibration procedure was carried out as follows. For each catchment of the dataset the model was run with $\mathrm{K}_{\mathrm{TC}-\mathrm{A}}$ values ranging from 5 to 50 and for $\mathrm{K}_{\mathrm{TC}-\mathrm{FP}}$ from 2 to 20 . For each parameter combination of $\mathrm{K}_{\mathrm{TC}-\mathrm{A}}$ and $\mathrm{K}_{\mathrm{TC}-\mathrm{FP}}$ an area specific sediment yield values was calculated for the 40 catchments. This allowed a comparison of the measured and predicted values for each parameter combination. The Model Efficiency (ME) as proposed by Nash and Sutcliffe (1970) was used as a measure of likelihood (Equation 7) .

$$
M E=1-\frac{\sum\left(S Y_{O B S}-S Y_{P R E D}\right)^{2}}{\sum\left(S Y_{O B S}-S Y_{M E A N}\right)^{2}} \quad \text { Equation } 7
$$

where ME is the model efficiency, $\mathrm{SY}_{\mathrm{OBS}}$ is the observed Sediment Yield, $\mathrm{SY}_{\mathrm{PRED}}$ is the predicted sediment yield and $\mathrm{SY}_{\mathrm{MEAN}}$ is the mean observed sediment yield. Values for ME range from $-\infty$ to 1 . The closer ME approximates 1 , the better the model will predict individual values. The results of these simulations are plotted in Figure 4.

\section{(FIGURE 4 NEAR HERE)}

\section{Figure 4 : Calibration of transport capacity parameters (left: KTC for forest- pasture, right: KTC for arable land)}

The results show an optimal value for KTC_FP at 12 and an optimal value for KTC_A at 30. Calibration curve of the KTC_FP has a very flat top from which it may be concluded 
that the model when applied to the complete dataset is not very sensitive to this parameter. With the optimal parameter values a model efficiency coefficient of -0.33 is obtained. This means that WaTEM/SEDEM is not efficient in predicting sediment yield if no differentiation is made between different landscape groups. Modelled versus osberved sediment yield are plotted in Figure 5.

(FIGURE 5 NEAR HERE)

Figure 5 : Observed versus predicted sediment yield (in ton.ha ${ }^{-1} \cdot \mathrm{y}^{-1}$ ) (transport capacity parameters derived from 'global' calibration procedure)

\section{RESULTS AND DISCUSSION}

When WaTEM/SEDEM is run with optimal model parameters the were derived via global calibration the correspondence between observed and predicted mean annual sediment yield values is relatively low with a correlation coefficient (R) of 0.21 . Moreover, the model efficiency (ME) is negative (-0.33), which means that the mean value of the dataset is on average a better estimate for an individual sediment yield value than a WaTEM/SEDEM model prediction. Nevertheless, Figure 5 shows a relative good correlation between observed and predicted values for catchments with an observed mean annual sediment yield higher than 3 ton.ha ${ }^{-1} \cdot \mathrm{y}^{-1}$. The model predictions for catchments with an observed mean annual sediment yield lower than 3 ton.ha ${ }^{-1} \cdot \mathrm{y}^{-1}$ are in general overestimations. Some of the sediment yield estimates for alpine catchments are outliers as the predicted values are more than 10 times higher than observed values.

Out of this observation may be concluded that for a more accurate application of WaTEM/SEDEM the calibration of the transport capacity coëfficients must be based on a set of similar catchments in terms of topography and land use. The calibration and application of WaTEM/SEDEM was for example relatively succesful in central Belgium (Van Rompaey et al., 2001) and the Czech Republic (Van Rompaey et al., 2003a). In both cases calibration was based on catchments with rather similar landscape properties: 
in Belgium rolling arable land on loess soils and in the Czech Republic a mixture of arable land, pasture and forest in an hilly environment.

The landscapes in the Italian catchments that are under investigation in this study, however, are very divers: semi-natural alpine mountain landscapes in the North-Italy, hilly areas with forest, arable land and vineyards in central Italy and semi-arid catchments with extensive agriculture and degraded land in South-Italy.

Therefore the catchment dataset was split in two groups: catchments with an average slope gradient over $40 \%$ and catchments with an average slope gradient under $40 \%$. Next, calibration of the transport capacity parameters was done for both groups separately (Figures 6 and 7).

(FIGURE 6 NEAR HERE)

Figure 6: Calibration for mountain catchments (slope gradient $>40 \%$ ) only

(FIGURE 7 NEAR HERE)

Figure 7: Calibration for non-mountain catchments (slope gradient $<40 \%$ )

An overview of the optimal parameter values derived via stratified and global calibration procedures is given in Table 2.

(TABLE 2 NEAR HERE)

\section{Table 2: Overview of optimal KTC-values for arable land (KTC_A) and pasture/forest (KTC_FP)}

Table 2 shows that the optimal transport capacity coefficients on arable land (KTC_Avalues) are similar in the mountain and non-mountain catchments. The calibration chart for KTC_A-values in the mountain catchments (Figure 6), suggest however, that the model is not very sensitive to this parameter which is logical as only a minor part of mountain catchments are under arable land. The similarity between KTC_A-values for mountain and non-mountain catchments is therefore not really significant. 
The optimal transport capacity coefficient for forest and pasture (KTC_FP-values), however, is significantly lower in mountain environments than in non-mountain environments. This suggests that under the same topographic circumstances gridcells under forest and pasture in mountain areas can transport less sediment than gridcells under forest and pasture in non-mountain catchments. A possible explanation for this finding is that forest and pasture in mountain catchments and non-mountain catchments have indeed a significantly different behaviour with respect to runoff generation and sediment transport due differences in erosion mechanisms and vegetation properties. It should however be kept in mind that sediment yield modelling consists of two components : 1) an assessment of the produced sediment. 2) an assessment of the total sediment delivery ratio. It is obvious that a systematic overprediction of soil erosion in mountain areas leads to the underestimation of the calibrated transport capacity coëfficients. In the ideal situation both model components are calibrated separately. This is, however, only possible for catchments where long-term soil loss rates are monitored. Observed verus predicted sediment yield with the optimal transport capacity parameters derived from the stratified calibration procedures are shown in Figure 8.

\section{(FIGURE 8 NEAR HERE)}

Figure 8: Observed versus predicted sediment yield (transport capacity derived via stratified calibration procedures)

The sediment yield predictions derived via stratified calibration procedures are more accurate than the predictions resulting from a global calibration procedure. The correlation between observed and predicted long term sediment yield is 0.50 and the model efficiency for the total dataset is 0.14 (see Table 2). Model predictions are more accurate for non-mountain catchments. The lower performance of WaTEM/SEDEM in the mountain catchments suggests that the model structure is possibly too simplefied for an accurate description of sediment flux processes in such environments. The erosion component of the model is based on a simplified USLE-2D (Desmet and Govers, 1996b) application which in principle only takes into account rill, interrill and gully erosion. Processes such as rockfall, avalanches and glacial erosion are not taken into account. 
Moreover, WaTEM/SEDEM assumes that the permanent river channels have an infinite transport capacity which means that rivers are not supposed to store sediment over longer timespans, which is obviously not always the case.

\section{CONCLUSIONS}

In this paper sediment fluxes in 40 Italian catchment were modelled with the best data available at national scale. Long term sedimentation records were used to validate the model results at the outlet. The catchments in the dataset are however very divers. Global calibration procedures that assume that the optimal transport capacity coefficients are similar in all catchments were not succesfull. A stratified calibration procedure whereby a distinction was made between mountain and non-mountain catchments resulted in a higher model performance. Better results where obtained if lower values are used for the transport capacity coefficient for forest and pasture in mountain catchments. It is, however, not clear wether these lower transport capacity coefficients represent real differences in sediment transport mechanisms or wether they are the logical consequence of a systematic overprediction of the sediment production in mountain environments. This problem can only be solved if data on erosion and deposition patterns within the catchments become available.

Even with optimal model parameters the performance of WaTEM/SEDEM is rather poor in the mountain catchments $(\mathrm{R}=0.25)$, which suggests that the processes included in the model are probably to simplied to come to an adequate description of the sediment fluxes. This finding is a strong plead for the development of parsimonious sediment flux models for mountain catchments that include all necessary processes but that are as simple as possible in order to facilitate their application at catchment scale.

The model performance for the non-mountain catchments in the dataset is better than for the mountain catchments $(\mathrm{R}=0.50)$. From land management point of view this finding is positive as to them it is much more important to predict accerated sediment fluxes under cropland than in (semi-)natural mountain areas. Similar model approaches in humid temperate areas resulted in higher model efficiencies. This may, however, at least partly be contributed to the fact that in this study datalayers with a $75 \mathrm{~m} \times 75 \mathrm{~m}$ resolution were 
used which is a much coarser grid than the $20 \mathrm{~m} \times 20 \mathrm{~m}$ resolution used in the other applications. Considering the fact that high resolution SRTM-elevation data (Shuttle Radar Topography Mission) will become available on a global scale, the results presented in this paper are at least promising.

Nevertheless, this study points out that the model concept of WaTEM/SEDEM not suitable for an accurate assessment of the complex sediment delivery processes in Alpine mountain catchments and that further research is necessary to fully understand and model such systems. 


\section{REFERENCES}

Bazzoffi, P., Baldassarre G., Vacca S. 1996. Validation of PISA2 model for automatic assessment of reservoir sedimentation. Proceedings of the International Conference on Reservoir Sedimentation. M.Albertson Ed. Colorado State Univ. 519-528.

Boardman, J., Ligneau, L., De Roo, A., Vandaele, K., 1994. Flooding of property by runoff from agricultural land in north-western Europe. Geomorphology, 10: 183-196.

Clark, E.H., 1985. The off-site costs of soil erosion. Journal of soil and water conservation, 40(1): 19-22.

COST Action 623 (European COorporation in the field of Scientific and Technical research), 1999, Soil erosion and global change. www.cost623.leeds.ac.uk.

Coulthard, T.J., Kirkby M.J., Macklin, M.G., 2000. Modelling geomorphic response to environmental change in an upland catchment. Hydrological Processes. 14(11-12): 20312045.

Coulthard, T.J., Macklin, M.G., Kirkby, M.J., 2002. A cellular model of Holocene upland river basin and alluvial fan evolution. Earth Surface Processes and landforms. 27(3): 269288

Crosson, P., 1997. Will erosion threaten agricultural productivity? Environment, 39 (8): 4-5.

De Roo, A.J.P., 1996, LISEM : an introduction. Hydrological Processes, 10(8), 10211025 . 
Desmet, P.J.J., Govers, G., 1996. A GIS-procedure for the automated calculation of the USLE LS-factor on topographically complex landscape units. Journal of Soil and Water Conservation, 51: 427-433.

Desmet, P.J.J., Poesen, J., Govers, G., Vandaele, K., 1999. Importance of slope gradient and contributing area for optimal prediction of the initiation and trajectory of ephemeral gullies. Catena, 37(3-4): 377-392.

Flaxman, E.M., 1972. Predicting Sediment Yield in the western United States. Proceedings of the ASCE, Journal of the Hydraulics Division, 98 : 2073-2085.

Grimm, M., Jones, R.J.A., Rusco, E., Montanarella, L., 2003. Soil erosion risk in Italy: a revised USLE approach. European Soil Bureau Research Report No. 11, EUR 19022 EN,

IGBP-BAHC (International Geosphere-Biosphere Programme), 1997. Modelling the transport and transformation of terrestrial materials to freshwater and coastal ecosystems, IGBP Report No. 39, IGBP, Stockholm, Sweden.

Lane, E.W., Koelzer, V.A., 1943. Density of sediments in reservoirs. In: A study of methods used in the measurements and analysis of sediments loads in streams. U.S. Corp of Engineers, Hydr.Lab. Iowa University.

Lara, J.M., Pemberton, E.L. 1963. Initial Unit Weight of deposit sediments. Proceedings of the Federal Inter-Agency Sedimentation Conference, Paper No. 82., USDA.

Lenhart, T., Van Rompaey, A., Steegen, A., Fohrer, N., Frede, H.G., Govers, G., 2003. A modification of the sediment routines in SWAT: A simple approach to consider spatial distribution and deposition, Hydrological Processes, in press. 
Lixian, W., Lida, S., Xijing, H., Bogging, Z., Qingyu, W., Guiyun, L., 1996. Application of regression analysis to the prediction of average annual yield of silt. In: Lixian, W. (ed.) Combating desertification in China, China Forestry Publishing House : 210-221.

McCool, D.K., Brown, L.C., Foster, G.R., Mutchler, C.K. and Meyer, L.D., 1987. Revised slope steepness factor for the Universal Soil Loss Equation. Transactions of the ASAE, 30: 1387-1396.

McCool, D.K., G.R. Foster, C.K. Mutchler, and L.D. Meyer, 1989. Revised Slope Length Factor for the Universal Soil Loss Equation. Transactions of the ASAE, 32(5), 15711576.

Morgan, R.P.C., Quinton, J.N., Smith, R.E., Govers, G., Poesen, J.W.A., Auerswald, K., Chisci, G., Torri, D., Styczen, M.E., 1998. The European Soil Erosion Model (EUROSEM) : A dynamic approach from predicting sediment transport from fields and small catchments. Earth Surface Processes and Landforms, 23 : 527-544.

Nash, J.E., Sutcliffe, J.V., 1970. River flow forecasting through conceptual models. Part I. A discussion of principles. Journal of Hydrology, 10: 282-290.

Nearing, M.A., Foster, G.R., Lane, L.J., Finkner, S.C., 1989 : A process-based soil erosion model for USDA-Water Erosion Prediction Project Technology. Transactions of the ASAE, $32: 1587-1593$.

Onstad, C.A., 1984. Sediment yield modelling. In : Hadley, R.F., Walling, D. : Erosion and sediment yield: some measurements of measuring and modelling. Geobooks, Norwich, England : 71-89.

Pimentel, D., Harvey, C., Resosudarmo, P., Sinclair, K., Kurz, D., McNair, M., Crist, S., Shpritz, L., Fitton, L., Saffouri, R., Blair, R., 1995. Environmental and economic costs of soil erosion and conservation benefits. Science, 267(5201): 1117-1123. 
Römkens, M., Prasad, J., Poesen, J., 1987. Soil erodibility and properties. Transactions of the XIII Congress of International Society of Soil Science. Volume V: 492-504.

Sibbesen, E., 1995. Phosphorus, nitrogen and carbon in particle-size fractions of soils and sediments. In: Correl, A. (ed.) Surface runoff, erosion and loss of phosphorus at two agricultural soils in Denmark, plot studies 1989-1992, SP-report No. 11: 135-148.

Schmidt, J., Von Werner, M., Michael, A., 1999. Application of the EROSION 3D model to the CATSOP watershed, The Netherlands. Catena, 37(3-4) : 449-456.

Steegen , A., Govers, G., Nachtergaele, J., Takken, I., Beuselinck, L., Poesen, J., 2000. Sediment export by water from an agricultural catchment in the Loam Belt of central Belgium. Geomorphology 33: 25-36.

Steegen, A., Govers, G., Takken, I., Nachtergaele, J., Poesen, J., Merckx, R., 2001. Factors controlling sediment and phosphorus export from two Belgian agricultural catchments. Journal of Environmental Quality, 30(4): 1249-1258.

Turner, B.L., Clark, W.C., Kates, R.W., Richards, J.F., Matthews, J.T., Meyer, W.B. 1990. The earth as transformed by human action. Cambridge University Press.

van der Knijff, J.M., Jones, R.J.A., Montanarella, L. 1999. Soil erosion risk assessment in Italy. European Soil Bureau. EUR 19022 EN, 52pp.

van der Knijff, J., Jones, R.J.A., Montanarella, L., 2002. Soil Erosion Risk Assessment in Italy. In: J.L. Rubio, R.P.C Morgan, S. Asins and V. Andreu (eds). Proceedings of the third International Congress Man and Soil at the Third Millennium. Geoforma Ediciones, Logrono. p.1903-1913. 
Van Oost, K., Govers, G., Desmet, P., 2000. Evaluating the effects of changes in landscape structure on soil erosion by water and tillage. Landscape Ecology, 15(6): 577589.

Van Rompaey, A.J.J., Verstraeten, Van Oost, K., G., Govers, G., Poesen, J., 2001. Modelling mean annual sediment yield using a distributed approach. Earth Surface Processes and Landforms, 26(11): 1221-1236.

Van Rompaey, A.J.J., Govers, G., Puttemans, C. 2002. Modelling land use changes and their impact on soil erosion and sediment supply to rivers. Earth Surface Processes and Landforms, 27(5): 481-494.

Van Rompaey, A., Krasa, J., Dostal, T., Govers, G., 2003a. Modelling sediment supply to rivers and reservoirs in Eastern Europe during and after the collectivisation period, Hydrobiologia, 494(1): 169-176.

Van Rompaey, A., Verstraeten, G., Van Oost, K., Rozanov, A., Govers, G., Poesen, J., 2003b. Modelling sediment fluxes in the Jonkershoek catchment. Part 1: Model calibration and validation, Proceedings of the workshop : Cartographic Modeling of Land Degradation (Ghent): pp. 75-89.

Verstraeten, G., Poesen, J. 1999. The nature of small-scale flooding, muddy floods and retention pond sedimentation in central Belgium. Geomorphology, 29(3-4): 275-292.

Verstraeten, G. Poesen, J., 2001. Factors controlling sediment yield from small intensively cultivated catchments in a temperate humid climate. Geomorphology, 40: 123-144.

Verstraeten, G., Poesen, J., de Vente, J., Koninckx, X., 2003. Sediment yield variability in Spain: a quantitative and semi-quantitative analysis using reservoir sedimentation rates. Geomorphology, 50: 327-348. 
Walling, D.E., 1983. The sediment delivery problem. Journal of Hydrology, 65 : 209237. 
Table 1: Properties of 40 Italian catchments (ISSDS, Firenze)

\begin{tabular}{|c|c|c|c|c|c|c|}
\hline Catchment & $\begin{array}{l}\text { Size } \\
\left(\mathrm{km}^{2}\right)\end{array}$ & $\begin{array}{c}\text { Av. Slope Gr. } \\
(\%)\end{array}$ & $\begin{array}{c}\text { Annual Precip. } \\
(\mathrm{mm})\end{array}$ & $\begin{array}{c}\text { Drain. Dens. } \\
(1 / \mathrm{km}) \\
\end{array}$ & $\begin{array}{c}\% \text { Arable Land } \\
(\%)\end{array}$ & $\begin{array}{l}\text { Obs. SSY } \\
\text { (ton/ha/y) }\end{array}$ \\
\hline ANCIPA & 50 & 17.8 & 837 & 2.0 & 0.0 & 5.6 \\
\hline BARCIS & 390 & 59.9 & 1644 & 4.3 & 1.2 & 5.2 \\
\hline BAU MELA & 95 & 26.2 & 967 & 3.8 & 33.9 & 0.7 \\
\hline BORECA & 42 & 44.7 & 883 & 2.9 & 1.3 & 0.9 \\
\hline CAMPO TARTANO & 48 & 55.0 & 1617 & 1.9 & 0.0 & 0.9 \\
\hline CARONA & 45 & 49.2 & 2012 & 3.0 & 0.7 & 0.2 \\
\hline CASTELLO & 68 & 48.4 & 1123 & 6.9 & 0.0 & 3.7 \\
\hline CIGNANA & 12 & 51.0 & 936 & 1.0 & 0.0 & 0.0 \\
\hline DISUERI & 249 & 11.3 & 607 & 2.2 & 67.3 & 16.8 \\
\hline FLUMENDOSA & 602 & 26.3 & 765 & 3.1 & 20.0 & 0.9 \\
\hline FORTEZZA & 661 & 49.2 & 907 & 4.0 & 0.5 & 0.6 \\
\hline GAMMAUTA & 91 & 24.3 & 796 & 3.7 & 71.7 & 1.6 \\
\hline LAVAGNINA & 43 & 30.4 & 1115 & 6.1 & 0.9 & 4.1 \\
\hline LETINO & 13 & 24.3 & 1406 & 0.6 & 7.7 & 0.5 \\
\hline LOCONE & 245 & 6.9 & 707 & 2.4 & 87.8 & 1.7 \\
\hline MAIRA & 54 & 50.3 & 990 & 2.1 & 1.7 & 0.2 \\
\hline MIGNANO & 87 & 20.5 & 877 & 4.0 & 39.2 & 12.8 \\
\hline MOLATO & 81 & 19.6 & 792 & 4.1 & 47.8 & 10.1 \\
\hline MULARGIA & 171 & 11.9 & 741 & 3.3 & 35.8 & 10.3 \\
\hline MURO LUCANO & 36 & 19.6 & 871 & 2.9 & 33.8 & 12.2 \\
\hline ORTIGLIETTO & 142 & 22.1 & 1027 & 6.2 & 3.8 & 6.9 \\
\hline OZOLA & 11 & 37.1 & 1414 & 2.0 & 0.0 & 2.5 \\
\hline PAGNONA & 55 & 58.4 & 1490 & 4.1 & 0.0 & 0.5 \\
\hline PAVANA & 40 & 36.5 & 1304 & 5.9 & 0.7 & 2.7 \\
\hline PLACE MOULIN & 68 & 60.2 & 857 & 0.7 & 0.0 & 2.3 \\
\hline PONTE FONTANELLE & 352 & 19.6 & 750 & 3.0 & 15.5 & 6.7 \\
\hline PONTECOSI & 234 & 31.9 & 1353 & 3.6 & 14.7 & 1.6 \\
\hline POZZILLO & 578 & 16.9 & 765 & 2.3 & 52.6 & 19.6 \\
\hline PRIZZI & 21 & 14.5 & 780 & 2.8 & 76.8 & 5.7 \\
\hline QUARTO & 219 & 26.0 & 1049 & 2.6 & 25.6 & 12.0 \\
\hline RIOLUNATO & 155 & 30.3 & 1257 & 3.8 & 21.1 & 4.7 \\
\hline ROCHEMOLLES & 24 & 49.8 & 736 & 1.8 & 0.0 & 0.1 \\
\hline SANTA LUCE & 40 & 9.9 & 966 & 3.8 & 69.6 & 9.2 \\
\hline SCALERE & 14 & 25.1 & 1180 & 4.0 & 47.0 & 0.9 \\
\hline SCANDARELLA & 39 & 15.2 & 913 & 3.7 & 24.9 & 4.9 \\
\hline SERRA DI CORVO & 298 & 5.7 & 737 & 2.4 & 87.9 & 1.9 \\
\hline SUVIANA & 75 & 33.4 & 1316 & 5.2 & 3.7 & 3.8 \\
\hline TORRE CROSIS & 86 & 41.2 & 2377 & 4.5 & 4.4 & 1.2 \\
\hline VODO & 333 & 44.6 & 1232 & 1.9 & 0.6 & 1.2 \\
\hline
\end{tabular}


Table 2: Optimal KTC-values derived from global and stratified calibration procedures

\begin{tabular}{cccccc}
$\begin{array}{c}\text { Calibration } \\
\text { Type }\end{array}$ & Dataset & KTC_FP & KTC_A & ME & R \\
\hline Global & total dataset & 12 & 30 & -0.33 & 0.21 \\
Global & mountain catchments & 12 & 30 & -6.62 & 0.20 \\
Global & non-mountain & 12 & 30 & -0.11 & 0.36 \\
& catchments & & & & \\
Stratified & total dataset & $8 / 16$ & $30 / 35$ & 0.14 & 0.50 \\
Stratified & mountain catchments & 8 & 30 & 0.07 & 0.25 \\
Stratified & non-mountain & 16 & 35 & 0.19 & 0.51 \\
& catchments & & & & \\
\hline
\end{tabular}


(a)

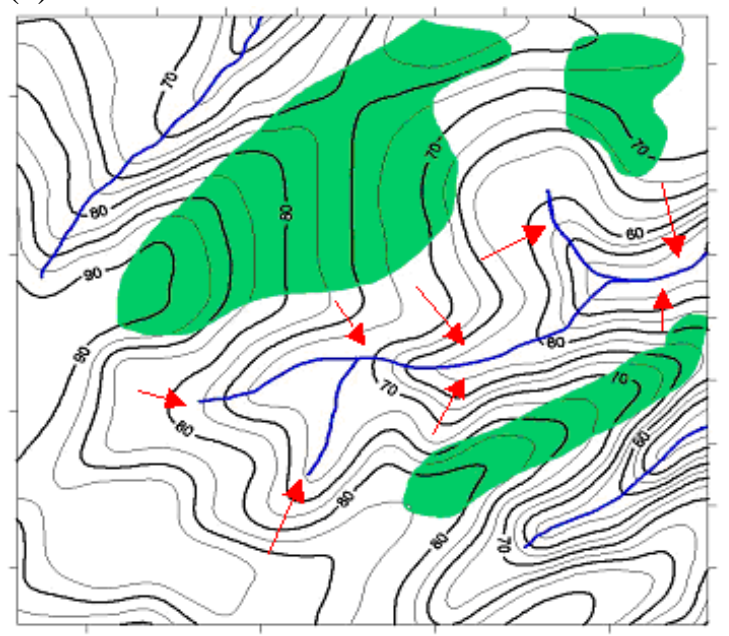

Forest (b)

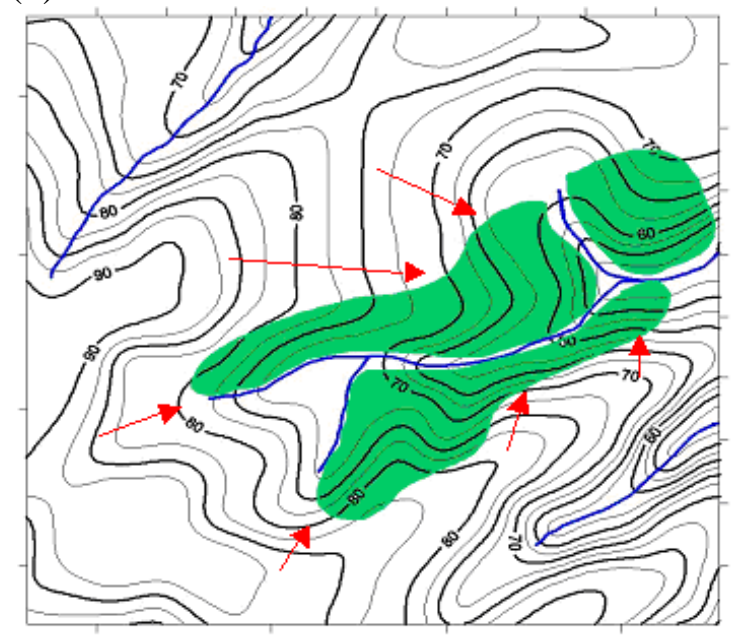

$\longrightarrow$ Sediment Flux

Figure 9: Two theoretical land use scenarios ((a) with high SY, (b) with low SY) 
(a)

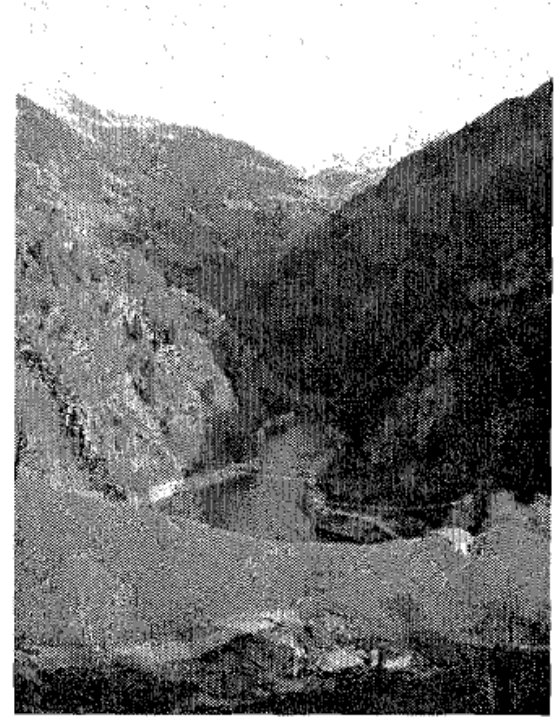

(b)

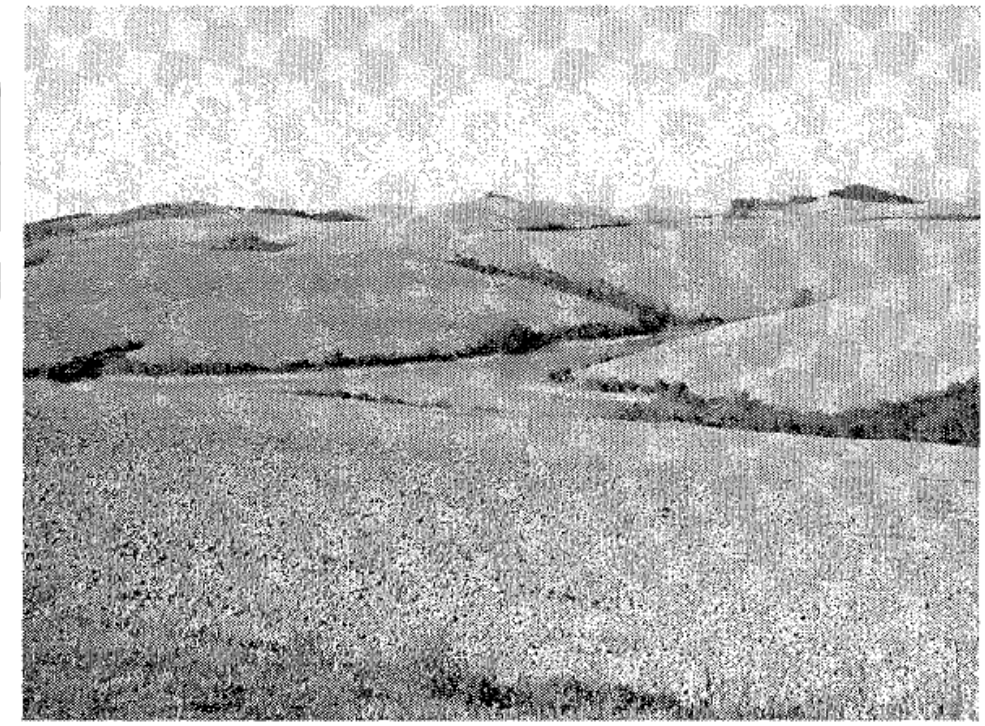

Figure 10: (a) Reservoir in Campo-Tartano (Lombardy, Italy), (b) Reservoir in Volterra (Tuscany, Italy) 


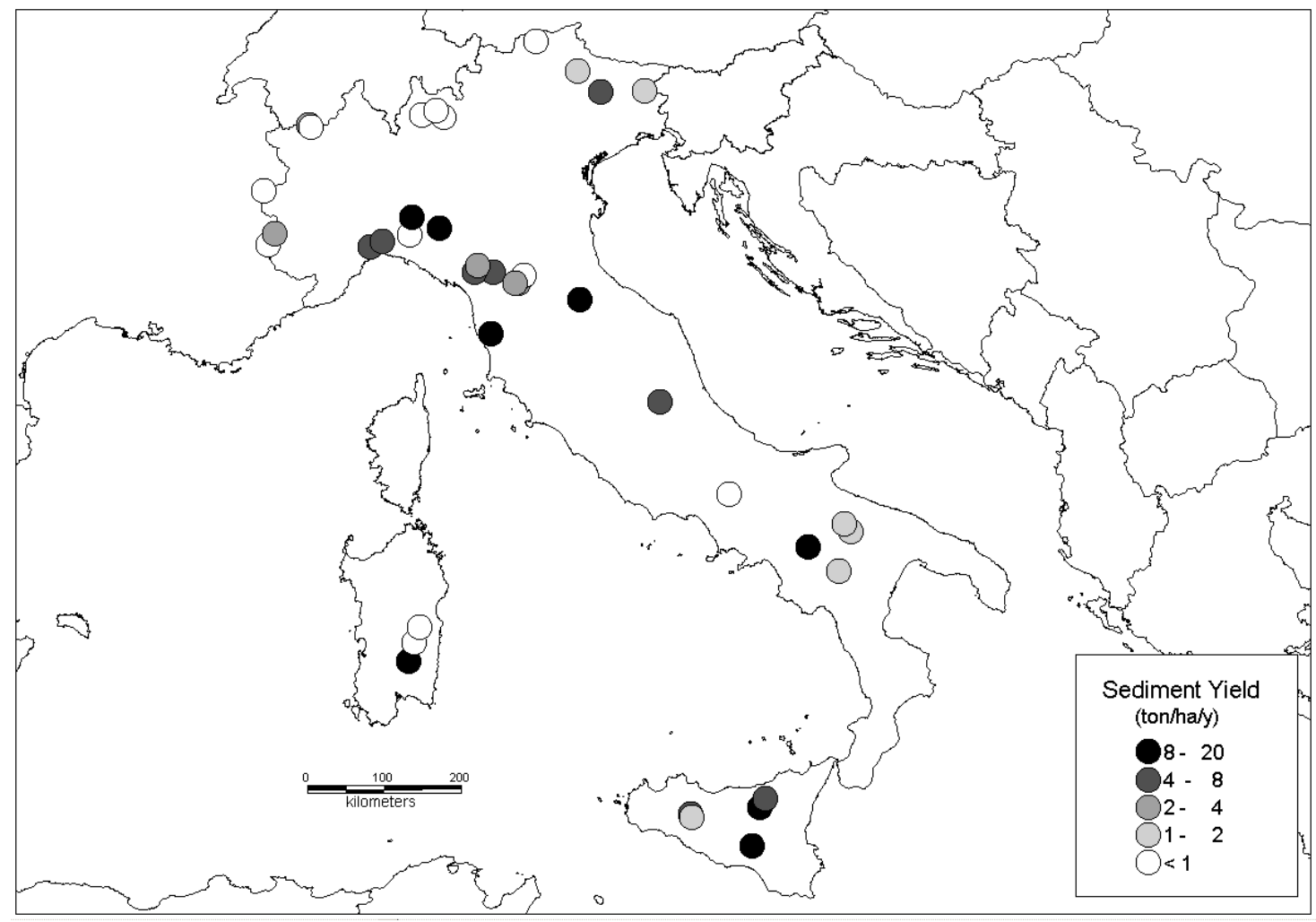

Figure 11: Location of 40 catchments with measured sediment yield (SY) at the outlet 

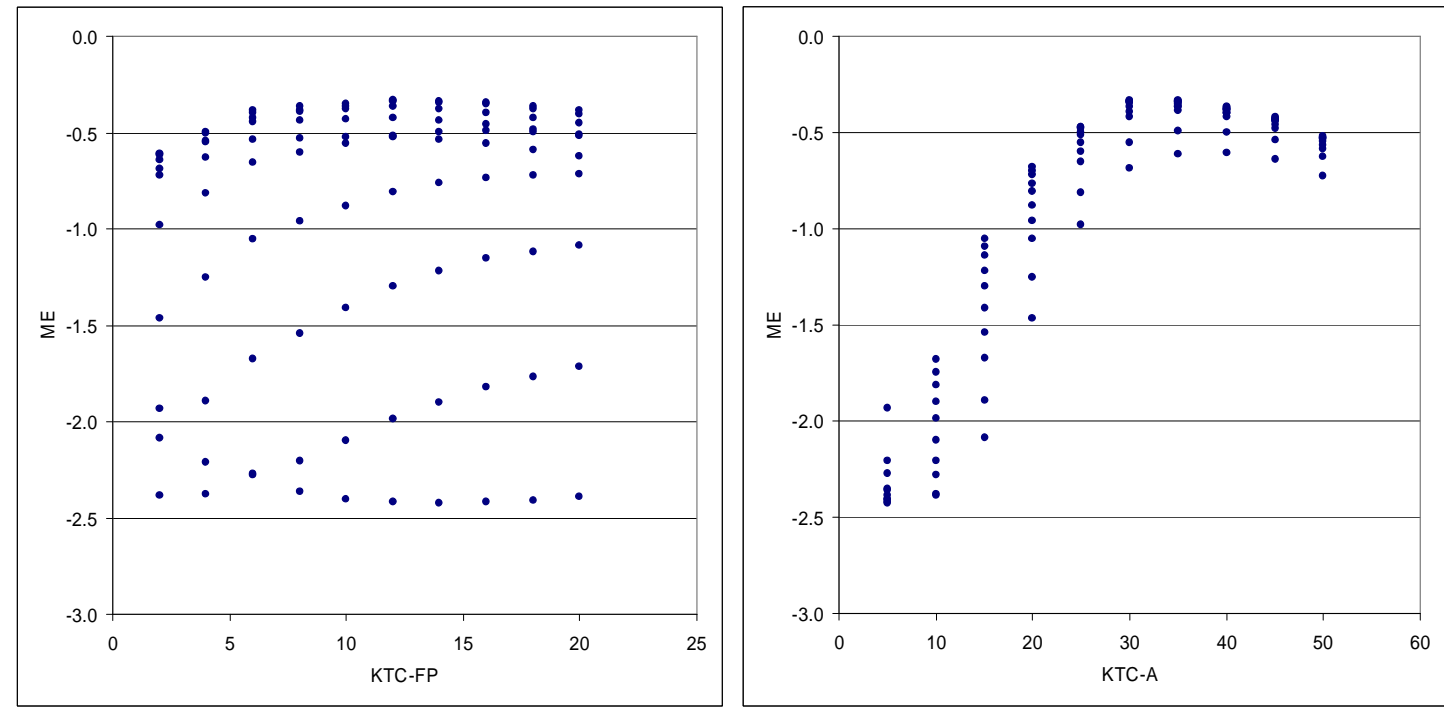

Figure 12 : Calibration of transport capacity (TC) parameters using a global calibration procedure (left: TC for forest-pasture, right: TC for arable land) 


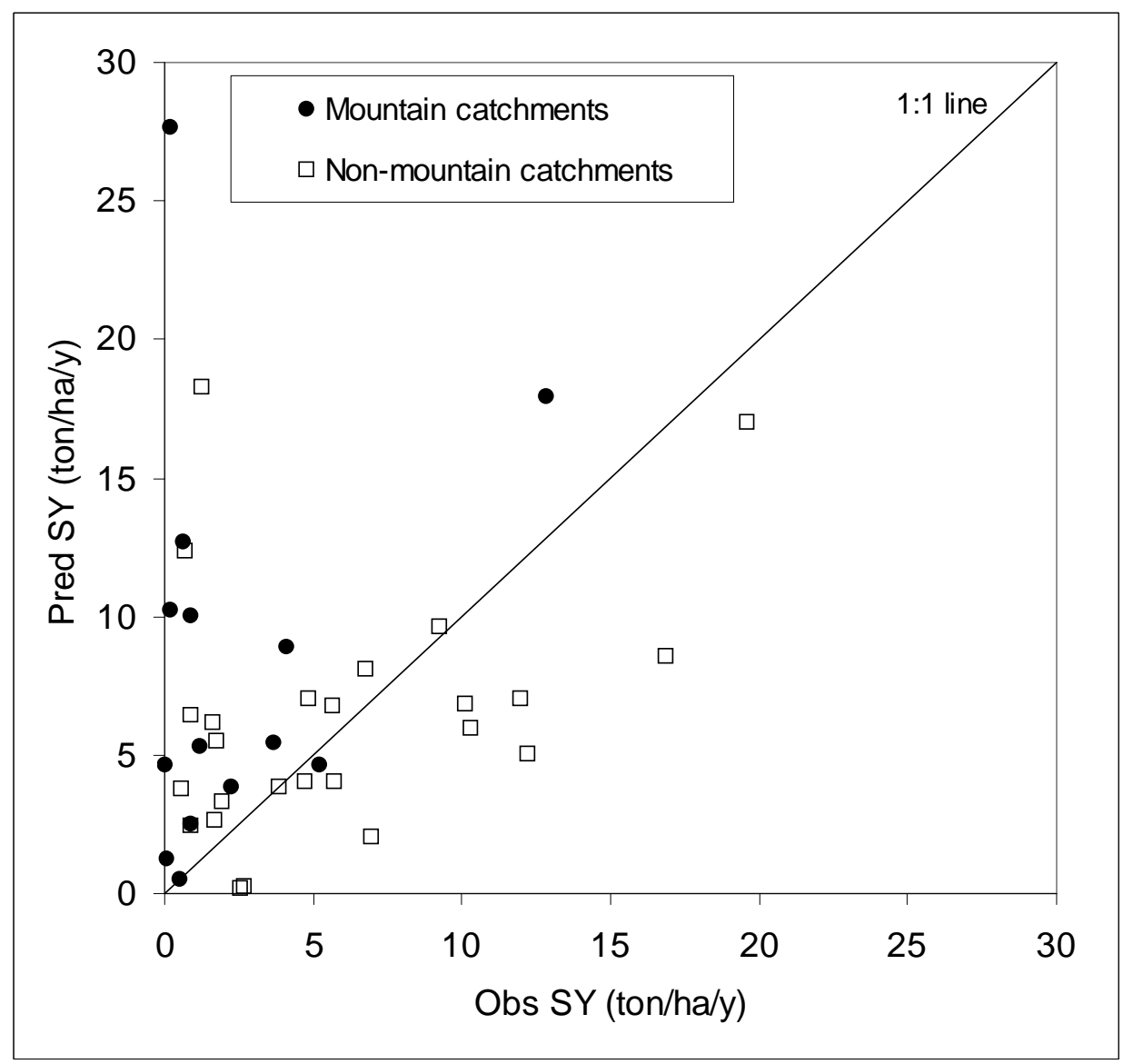

Figure 13 : Observed versus predicted sediment yield (in ton/ha/y) (transport capacity parameters derived via a global calibration procedure) 

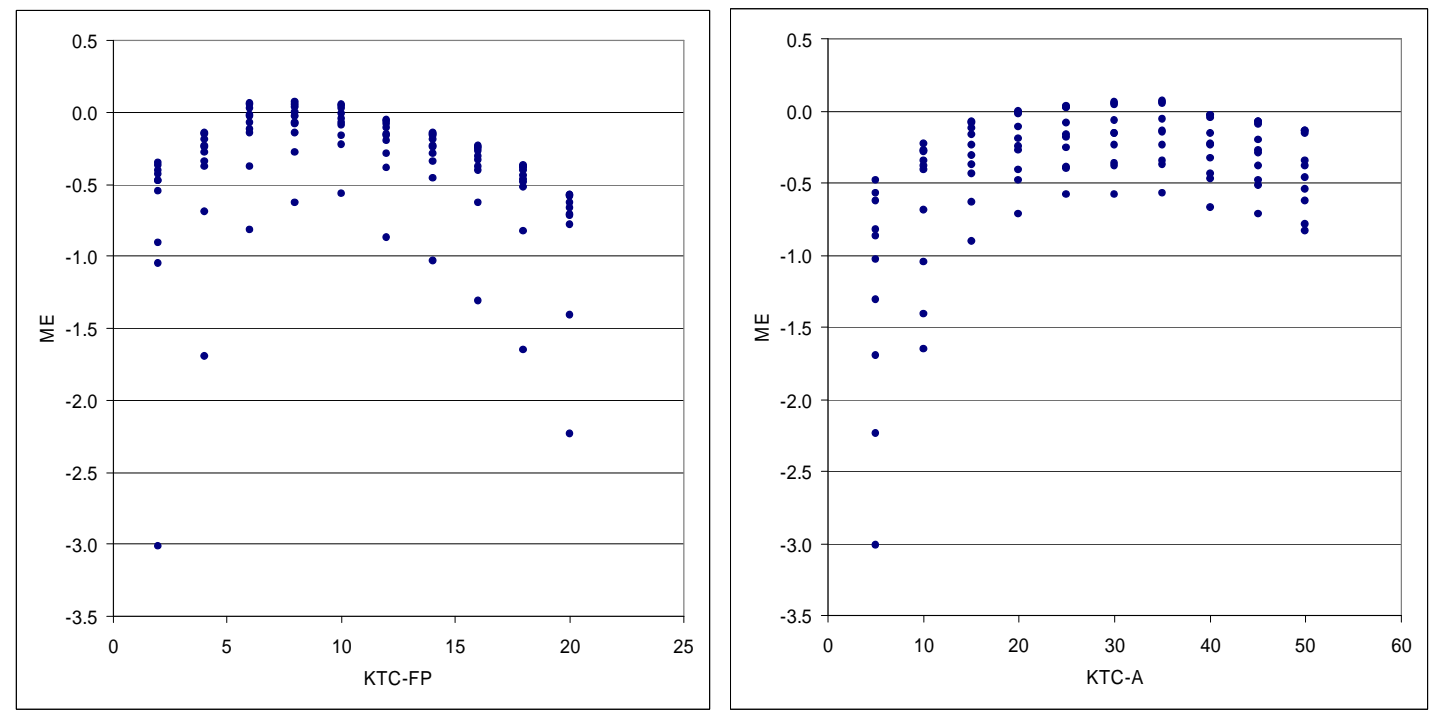

Figure 14: Calibration for mountain catchments (slope gradient $>40 \%$ ) only 

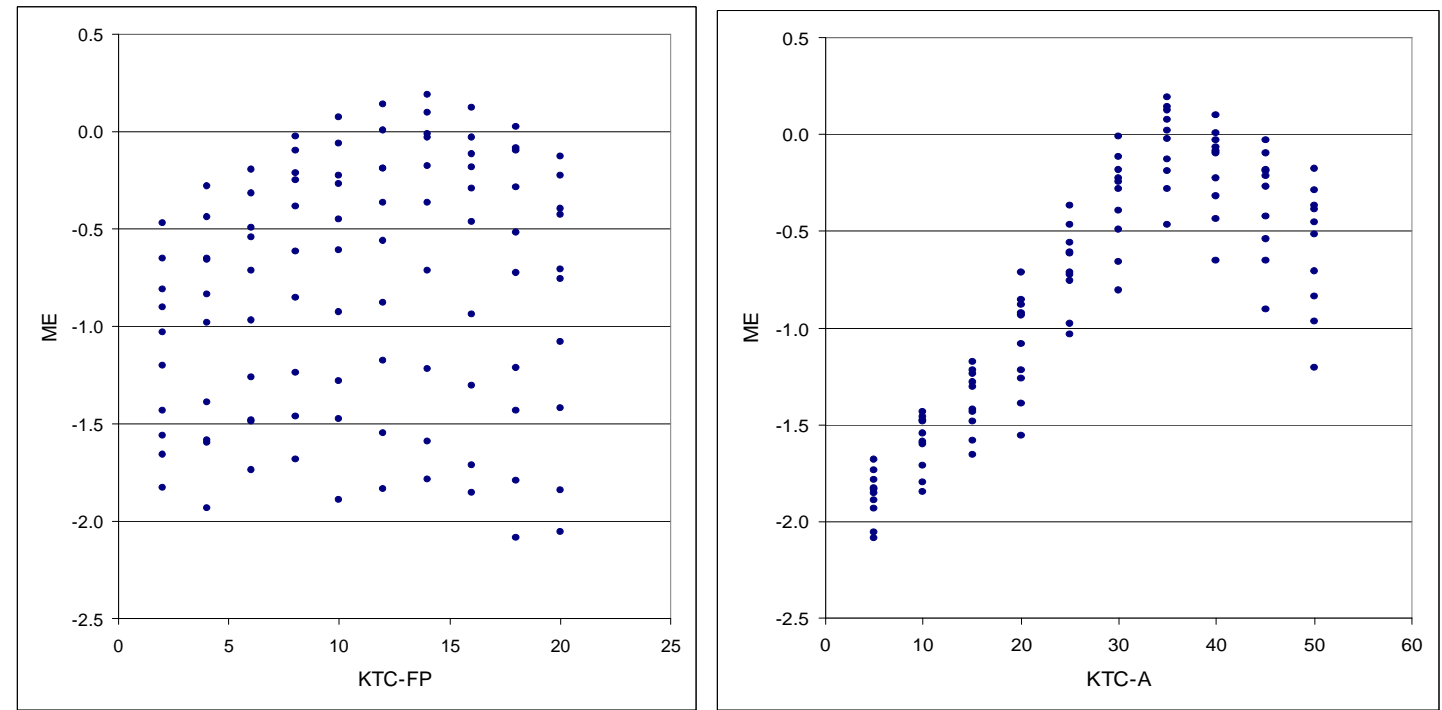

Figure 15: Calibration for non-mountain catchments (slope gradient $<40 \%$ ) using a stratified calibration procedure 


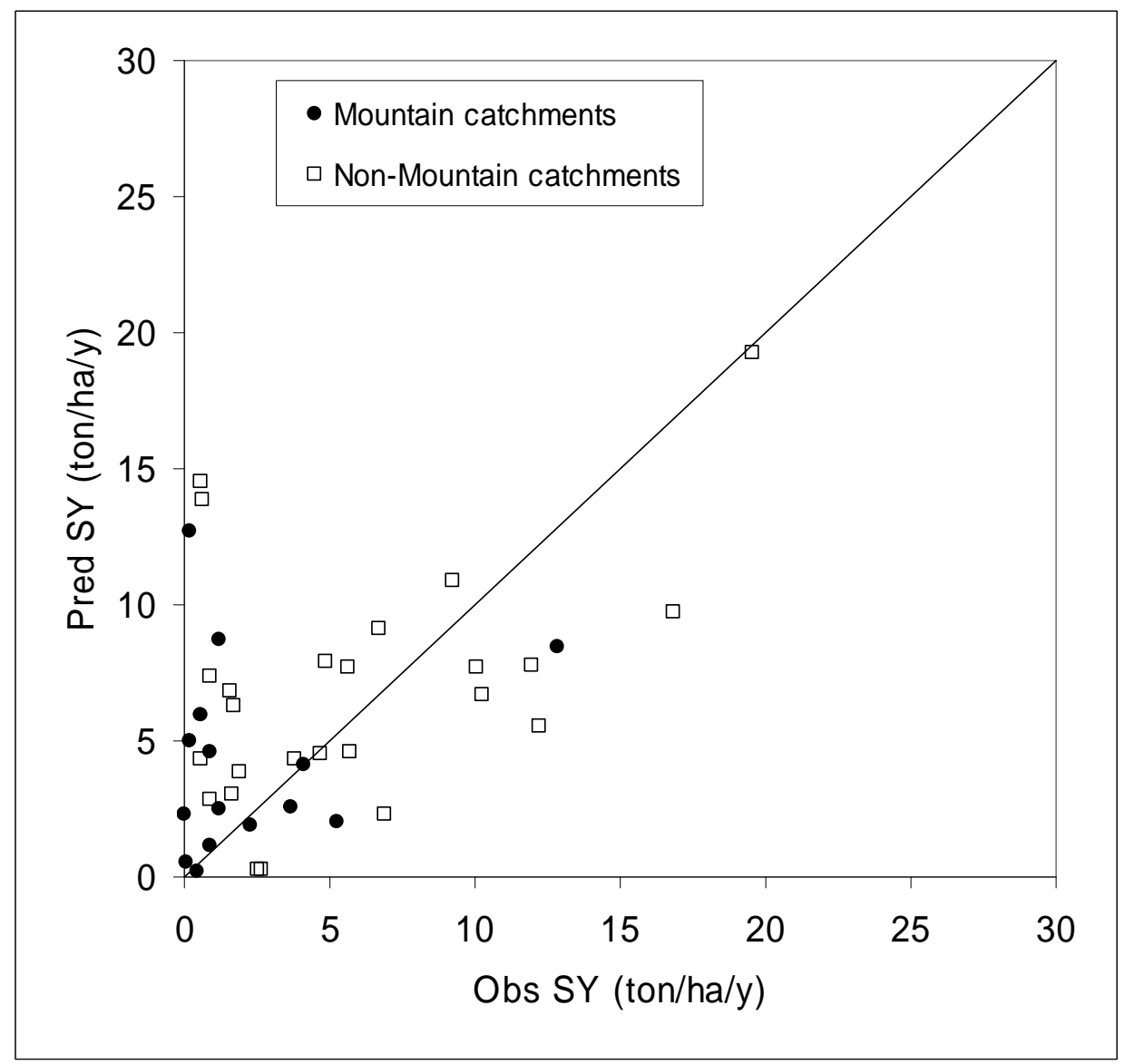

Figure 16: Observed versus predicted sediment yield in ton/ha/y (transport capacity derived from stratified calibration procedures) 